\title{
Trace metals in populations of Marphysa sanguinea (Montagu, 1813) from Sado estuary: effect of body size on accumulation
}

\author{
JOÃO GARCÊS ${ }^{1}$ and M. HELENA COSTA ${ }^{2}$ \\ ${ }^{1}$ Instituto Nacional de Investigação Agrária e das Pescas (IPIMAR), Avenida de Brasília 1449-006 Lisboa, Portugal. \\ E-mail: jgarces@ipimar.pt \\ ${ }^{2}$ IMAR - Instituto do Mar, Depto de Ciências e Eng ${ }^{a}$ do Ambiente, Faculdade de Ciências e Tecnologia, Universidade \\ Nova de Lisboa, Campus da Caparica, 2829-516 Caparica, Portugal.
}

\begin{abstract}
SUMMARY: Concentrations of $\mathrm{Fe}, \mathrm{Zn}, \mathrm{Cu}, \mathrm{Pb}$ and $\mathrm{Cd}$ were measured in four surface sediments, whole worm tissues and faeces collected along Águas de Moura channel in Sado estuary. Six wet-weight worm classes were used to analyze the influence of weight. The metal concentration in colonized sediments is high for $\mathrm{Fe}$ and $\mathrm{Cu}$, moderate for $\mathrm{Pb}$ and $\mathrm{Zn}$, and low for $\mathrm{Cd}$. The analyses of whole worm tissues show that $\mathrm{Zn}, \mathrm{Cd}$ and $\mathrm{Cu}$ are accumulated. Considering the elevated sediment concentrations to which this species is exposed, the high levels of $\mathrm{Zn}$ and $\mathrm{Cu}$ suggest sequestration and $\mathrm{Cu}$ adaptation. However, the low Fe concentration indicates that this metal is not readily available. The similar $\mathrm{Pb}$ behaviour also suggests low availability or $\mathrm{Fe}$ interference. The high correlation in the sediment between $\mathrm{Pb}$ and $\mathrm{Fe}$ reinforces this suggestion. The results obtained show that $\mathrm{Pb}, \mathrm{Zn}$ and $\mathrm{Fe}$ are the most important metals in the different weight classes. The overall results of this study show: (1) that this worm is able to adapt physiologically to elevated levels of metals; and (2) that the weight of the worms needs to be taken into account in environmental management programmes.
\end{abstract}

Keywords: bioaccumulation, Marphysa sanguinea, Sado estuary, sediment contamination, trace metal.

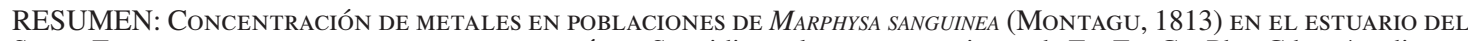
SAdo: EfeCto de SU PESO EN la bioACUMUlación. - Se midieron las concentraciones de $\mathrm{Fe}, \mathrm{Zn}, \mathrm{Cu}, \mathrm{Pb}$ y Cd en 4 sedimentos de superficie, tejidos y excrementos de poliquetos recogidos en el canal de Agua de Moura, en el estuario del Sado. Para estudiar la influencia del peso se analizaron los poliquetos en 6 grupos de acuerdo con su peso húmedo. La concentración de metales en los sedimentos colonizados fue alta en $\mathrm{Fe}$ y $\mathrm{Cu}$, moderada en $\mathrm{Pb}$ y $\mathrm{Zn}$, y baja en $\mathrm{Cd}$. Los resultados muestran que el $\mathrm{Zn}, \mathrm{Cu}$ y $\mathrm{Cd}$ se acumulan en los tejidos. Los altos niveles de $\mathrm{Cu}$ y $\mathrm{Zn}$ sugieren secuestro y la existencia de una adaptación al $\mathrm{Cu}$, relacionada con los altos niveles existentes en el sedimento. Por el contrario, la baja concentración de Fe indica una baja disponibilidad. El comportamiento similar del Pb también sugiere una baja disponibilidad y una injerencia de Fe. De hecho, la correlación significativa $(\mathrm{p}<0.01)$ entre estos dos metales en el sedimento, refuerza esta sugerencia. Las altas excreciones de $\mathrm{Fe} \mathrm{y} \mathrm{Pb}$ y reducidas de $\mathrm{Zn}$, $\mathrm{Cu}$ y $\mathrm{Cd}$, viene a reforzar las sugerencias anteriores. Con respecto a la influencia del peso, los resultados demuestran que $\mathrm{Pb}, \mathrm{Zn}$ y Fe son los metales más importantes en la diferenciación de las clases de peso. En conjunto, este estudio demuestra (1) que este poliqueto tiene la capacidad de adaptarse fisiológicamente a los elevados niveles de $\mathrm{Fe}$ y $\mathrm{Cu}$ y (2) que en programas de monitorización ambiental es importante tener en consideración el factor peso.

Palabras clave: bioacumulación, Marphysa sanguinea, estuario del Sado, contaminación del sedimento, metales traza.

\section{INTRODUCTION}

Estuaries are areas of high productivity, crucial in the life history of many fish, invertebrates and birds. The sustainability of estuarine biodiversity is vital to the ecological health of coastal regions. Estuaries also rank among the most anthropogenic ecosystems on earth and are subjected to intensive environmental pressures. In particular, sediments can act as a sink and cycling centre for metallic contaminants, and 
therefore can be a potential source for metal bioaccumulation by marine deposit and suspension feeding invertebrates, which may have adverse effects at complex levels of biological organization (Lee et $a l ., 2000)$. One major concern with the chemicals associated with sediments is that many commercial species, and their preys, are particularly vulnerable to toxic compounds given their close contact with sediment particles and interstitial water for extended periods of their life cycle. This provides a pathway for these chemicals to be transferred directly from sediments to organisms (Wright and Mason, 1999). Determining the ecological significance of trace metal contamination in sedimentary environments is difficult. Uptake and effects of sediment-associated contaminants are largely a function of bioavailability, which is strongly influenced by a set of physical, chemical and biological factors in the sediments. While most metals are naturally present in the aquatic environment, it is their presence at elevated concentrations that is a potential threat to aquatic life (Rainbow et al., 1990).

It is important, therefore, to determine whether ecologically keystone species of our estuaries are at risk due to toxic contaminants or whether different local populations are tolerant to bioavailable levels of toxicants that are potentially lethal elsewhere. In Sado estuary M. sanguinea is a herbivorous and surface detritivorous feeder with moderate or discreet surface mobility. It inhabits the intertidal mudflats of estuaries and coastal zones. It is broadly distributed in Sado estuary (Portugal) wetlands, where it lives in deep borrows, and is particularly abundant in old oyster production areas. It is among the key species in Sado estuary, and functions as a major constituent of the benthic biomass of mudflats as well as an important food item for crustaceans, fishes and waders (Castro, 1993). M. sanguinea is also commonly used as fresh bait and harvesting it is one of the most important socio-economic resources for local fishermen.

The purpose of this study is to evaluate the influence of weight on the bioaccumulation of sedimentbound $\mathrm{Fe}, \mathrm{Zn}, \mathrm{Cu}, \mathrm{Pb}$ and $\mathrm{Cd}$ in $M$. sanguinea in Águas de Moura Channel, located in central Sado estuary.

\section{MATERIAL AND METHODS}

\section{Study area}

Sado estuary is located on the southwest coast of Portugal $\left(37^{\circ} 25^{\prime}-38^{\circ} 40^{\prime} \mathrm{N}, 0.07^{\circ} 40^{\prime}-0.08^{\circ} 5 \mathrm{O}^{\prime} \mathrm{W}\right)$ (Fig. 1). It is an area of $180 \mathrm{~km}^{2}$, of which $62 \%$ is wetlands with a complex morphology. It is a mesotidal coastal-plain lagoon-type estuary well mixed for normal river flow conditions, although high discharge in some winter months may cause moderate stratification in parts of the estuary (Caeiro et al., 2005a; Ferreira et al., 2003). Most of the estuary is classified as a Nature Reserve and it is also a Ramsar site due to the high biodiversity values. Sado estuary is subjected to intensive land use practices, which play an important role in the local and national economy.

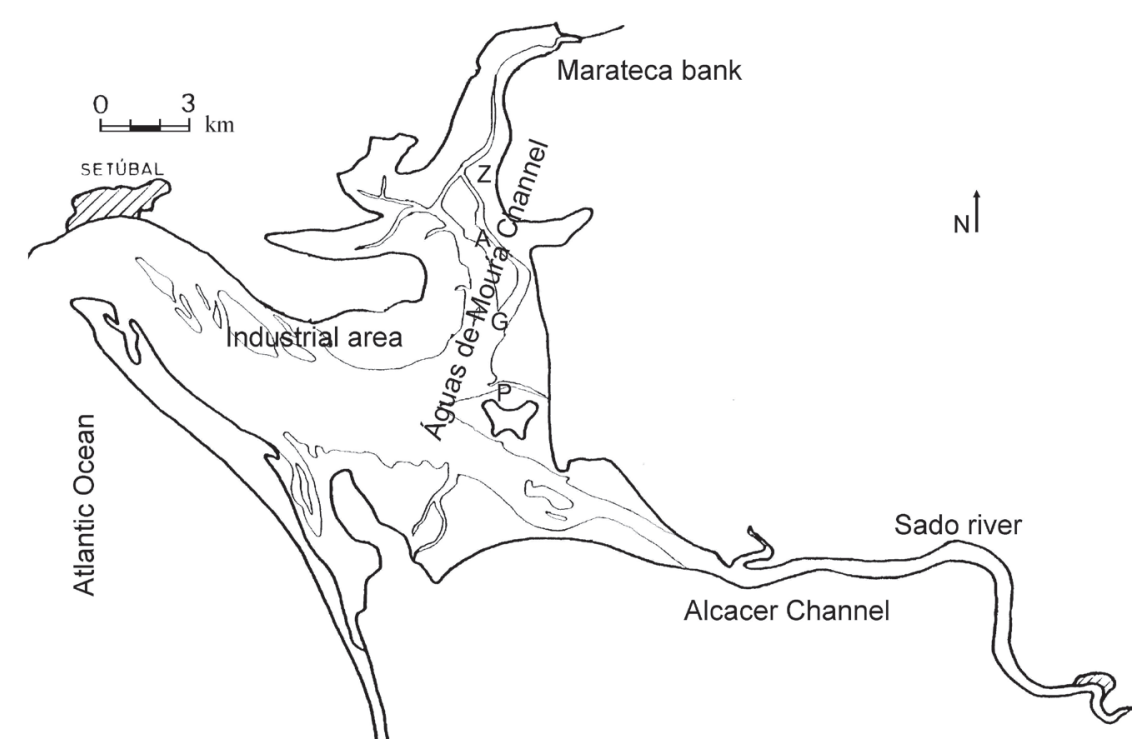

FIG. 1. - Sado estuary, South Portugal. Letters and points indicate sampling sites: Z, Zambujal; A, Arrábidas; G, Garças; P, Pinheiro. 
TABLE 1. - Number of worms analyzed in sampling stations and in the 6 wet-weight classes (g)

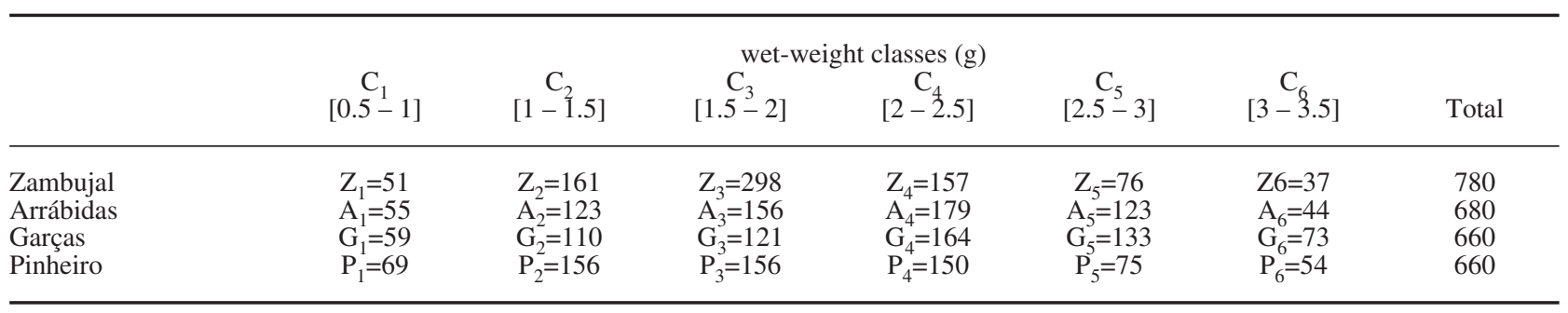

The study site located in Águas de Moura Channel is quite shallow. It is intertidal with the largest salt marsh area of the estuary, where Marphysa sanguinea reaches high densities. It is also a high salinity area where hydrodynamic properties, nutrient dynamics and primary productivity patterns are very different from those in the adjacent areas (Cabeçadas et al., 2000). Four sampling stations (Zambujal (Z), Arrábidas (A), Garças (G) and Pinheiro (P)) were chosen according to the density of $M$. sanguinea, and avoiding intense harvesting sites.

\section{Methodology}

Sediment and worms were collected at low tide in April 2002 at each station. Sediment triplicate samples were collected with a previously acid washed cylindrical plastic tube (15 $\mathrm{cm}$ in diameter) placed directly on the gallery of the polychaete to a depth of $30 \mathrm{~cm}$, immediately sealed then transported to the laboratory and stored at $-80^{\circ} \mathrm{C}$ before chemical analysis. In the study area, the first $15 \mathrm{~cm}$ of the sediment samples were light-coloured and no $\mathrm{H}_{2} \mathrm{~S}$ smell was noticed during collection, which indicates an oxygenated top sediment layer. The collected worms were carefully washed with seawater from the collection site to eliminate sediment and other particles. In the laboratory, only the top fraction (5 $\mathrm{cm}$ ) of sediment was analyzed, and collected worms were divided into six weight classes (Table 1) and placed in polyethylene covered tanks that had been previously acid washed. The bottom of the tanks was continuously aerated and filled with a fine layer of treated calcined sand and $5 \mathrm{~m}^{3}$ of filtered water. The sand was previously screened through a $0.5 \mathrm{~mm}$ sieve in order to remove algae and any associated macrofauna. Afterwards, it was sterilized in an autoclave (during 20 minutes at $1 \mathrm{~atm}$ ) and then placed in a stove at $90^{\circ} \mathrm{C}$ during $24 \mathrm{~h}$. The worms were kept starved for $48 \mathrm{~h}$ in order to purge the gut contents and adhering sediment prior to metal analysis (Diéz et al., 2000). Water from Sado estuary was changed daily, damaged individuals were removed and the faeces in each of the weight classes were collected for subsequent analysis. Trace metals were determined by atomic absorption spectrophotometry (AAS) according to the procedure developed by Rantala and Loring (1977) for sediments and faeces, and Vale and Cortesão (1988) for tissues, using the multiple standard addition method.

Analyses of $\mathrm{Pb}$ and $\mathrm{Cd}$ in all samples and $\mathrm{Cu}$ in tissues were carried out with a Perkin Elmer Aanalyst 100 atomic absorption spectrophotometer equipped with a deuterium background corrector. Pyrolytically coated furnace tubes were used. The flame technique (a conventional air/acetylene flame - Perkin Elmer Aanalyst 100 equipped with background corrector) was used to analyze $\mathrm{Al}, \mathrm{Fe}$ and $\mathrm{Zn}$ in all samples and $\mathrm{Cu}$ in sediments and faeces. Al was only determined in sediment in order to remove the grain size effect associated with the natural inputs of the sedimentation process, which evidence the level of anthropogenic contribution (Loring, 1991; Langston, et al., 1999; Villares, et al., 2003). Procedural blanks were prepared and analyzed with the samples. International certified standards for sediments and faeces (MESS-1, MESS-2, BCSS-1 and 1646-a) and for tissues (DORM-1, DORM-2 and NBS-bovine liver) were used to control the accuracy of the procedures (Tables 2 and 3).

Statistical analysis was performed using SPSS (Statistical Package for the Social Sciences) software (Version 14; SPSS Inc, Chicago, IL). The relationships between metal concentrations and $\mathrm{Al}$ content in sediment were examined using Spearman's rank correlation. Concentrations in sampling sites (sediment and worm tissues) and metal concentration in each wet-weight class were compared using the Kruskal-Wallis one-way ANOVA followed by non-parametric multiple comparisons (LSD). A significance level of $\alpha=0.05$ was chosen. The effect of body weight on bioaccumulation was first evaluated by multidimensional scaling. The minimum number of dimensions necessary to 
TABLE 2. - Certified concentrations of $\mathrm{Fe}, \mathrm{Zn}, \mathrm{Cu}, \mathrm{Pb}$ and $\mathrm{Cd}\left(\mu \mathrm{g} \mathrm{g} \mathrm{g}^{-1} \mathrm{~d} . \mathrm{w}\right.$.) averaged over standard reference materials (DORM-1, DORM-2, NBS) and standard deviation ( \pm sd) for sediments and faeces; d.w., dry weight; Stand., Standard.

\begin{tabular}{|c|c|c|c|c|c|c|c|c|c|c|c|c|c|}
\hline & \multicolumn{6}{|c|}{ Sediment } & \multicolumn{6}{|c|}{ Faeces } \\
\hline & & $\mathrm{Al}(\%)$ & $\mathrm{Fe}(\%)$ & $\mathrm{Pb}$ & $\mathrm{Cu}$ & $\mathrm{Zn}$ & $\mathrm{Cd}$ & $\mathrm{Al}(\%)$ & $\mathrm{Fe}(\%)$ & $\mathrm{Pb}$ & $\mathrm{Cu}$ & $\mathrm{Zn}$ & $\mathrm{Cd}$ \\
\hline BCSS-1 & $\begin{array}{l}\text { Stand. } \\
\text { Work }\end{array}$ & $\begin{array}{c}6.3 \pm 0.2 \\
6.2\end{array}$ & $\begin{array}{c}3.3 \pm 0.1 \\
3.4\end{array}$ & $\begin{array}{c}22.7 \pm 3.4 \\
20.8\end{array}$ & $\begin{array}{c}18.5 \pm 2.7 \\
18.9\end{array}$ & $\begin{array}{c}119 \pm 12 \\
122\end{array}$ & & $\begin{array}{c}6.3 \pm 0.2 \\
6.3\end{array}$ & $\begin{array}{l}3.8 \\
3.4\end{array}$ & $\begin{array}{c}22.7 \pm 3.4 \\
25.7\end{array}$ & & $\begin{array}{c}119 \pm 12 \\
119\end{array}$ & \\
\hline MESS-1 & $\begin{array}{l}\text { Stand. } \\
\text { Work }\end{array}$ & & & & & $\begin{array}{c}191 \pm 17 \\
190\end{array}$ & $\begin{array}{c}0.6 \pm 0.1 \\
0.6\end{array}$ & $\begin{array}{l}5.8 \\
5.9\end{array}$ & & $\begin{array}{c}34 \pm 6.1 \\
37.3\end{array}$ & & $\begin{array}{c}191 \pm 17 \\
191\end{array}$ & \\
\hline MESS-2 & $\begin{array}{l}\text { Stand. } \\
\text { Work }\end{array}$ & & $\begin{array}{l}4.3 \\
4.2\end{array}$ & $\frac{21.9 \pm 0.01}{21}$ & $\begin{array}{c}39.3 \pm 2 \\
40.3\end{array}$ & $\begin{array}{c}172 \pm 2.5 \\
174\end{array}$ & $\begin{array}{c}0.2 \pm 0.01 \\
0.2\end{array}$ & & $\begin{array}{l}4.3 \\
4.2\end{array}$ & & $\begin{array}{c}39.3 \pm 2 \\
40.5\end{array}$ & $\begin{array}{c}172 \pm 3 \\
173.6\end{array}$ & $\begin{array}{c}0.2 \pm 0.01 \\
0.3\end{array}$ \\
\hline $1646-\mathrm{a}$ & $\begin{array}{l}\text { Stand. } \\
\text { Work }\end{array}$ & $\begin{array}{c}2.3 \pm 0.02 \\
2.3\end{array}$ & & & $\begin{array}{c}10 \pm 0.3 \\
11\end{array}$ & & & & & & & & $\begin{array}{c}0.4 \pm 0.07 \\
0.3\end{array}$ \\
\hline
\end{tabular}

TABle 3. - Certified concentrations of $\mathrm{Fe}, \mathrm{Zn}, \mathrm{Cu}, \mathrm{Pb}$ and $\mathrm{Cd}(u \mathrm{~g}$ $\mathrm{g}^{-1}$ d.w.) averaged over standard reference materials (DORM-1, DORM-2, NBS) and standard deviation $( \pm \mathrm{sd})$ for worm tissues; d.w., dry weight.

\begin{tabular}{|c|c|c|c|c|c|c|}
\hline & \multicolumn{2}{|c|}{ DORM-1 } & \multicolumn{2}{|c|}{ DORM-2 } & \multicolumn{2}{|c|}{ NBS } \\
\hline & Standard & Work & Standard & Work & Standard & Work \\
\hline $\mathrm{Fe}$ & $63.5 \pm 5.3$ & 56.2 & & & & \\
\hline $\mathrm{Zn}$ & $21.3 \pm 1$ & 24.6 & $25.6 \pm 2.3$ & 25.5 & & \\
\hline $\mathrm{Cu}$ & $5.2 \pm 0.3$ & 5.2 & & & & \\
\hline $\mathrm{Cd}$ & $0.1 \pm 0.01$ & 0.1 & $0.04 \pm 0.01$ & 0.03 & & \\
\hline $\mathrm{Pb}$ & $0.4 \pm 0.1$ & 0.5 & & & $0.4 \pm 0.01$ & 0.4 \\
\hline
\end{tabular}

reproduce the similarities/disparities between the wet-weight classes was evaluated according to the Scree-plot criterion and by graphic analysis of the proximities transformed vs. distances. This analysis was refined by a non-hierarchical cluster analysis (K-means). The R-squared method was used as the decision criterion for the number of clusters to retain. The more important metals in the retained clusters were identified by the distance between the centre of the clusters and a statistical cluster FAnova analysis. The error probabilities associated with cluster results was evaluated with a two-way discriminant analysis (Wilks' lambda $(\wedge)$ and the Mahalanobis distance $\left.\left(\mathrm{DM}^{2}\right)\right)$. The variance-covariance normality and homogeneity of each group were tested with Shapiro-Wilk and M-Box tests respectively. A collinearity analysis was carried out in order to reinforce the results obtained.

\section{RESULTS}

\section{Metals in sediment}

The relationships between concentrations of pairs of metals in sediments (Table 4) show that only Fe and $\mathrm{Pb}$ concentrations are significantly $(\mathrm{p}<0.01)$ correlated to $\mathrm{Al}$ content.
TABLE 4. - Relationships (measured by Spearman rank correlation) between metals in surface sediments (top $5 \mathrm{~cm}$ ) of central Sado estuary.

\begin{tabular}{lcccccc}
\hline & $\mathrm{Al}$ & $\mathrm{Fe}$ & $\mathrm{Pb}$ & $\mathrm{Zn}$ & $\mathrm{Cu}$ & $\mathrm{Cd}$ \\
\hline $\mathrm{Al}$ & 1.00 & $0.96(* *)$ & $0.72(* *)$ & 0.05 & -0.37 & 0.005 \\
$\mathrm{Fe}$ & ------ & 1.00 & $0.72(* *)$ & -0.07 & -0.50 & -0.03 \\
$\mathrm{~Pb}$ & ----- & ---- & 1.00 & 0.49 & -0.37 & 0.28 \\
$\mathrm{Zn}$ & ------ & ---- & ---- & 1.00 & -0.02 & $0.61(*)$ \\
$\mathrm{Cu}$ & ------ & ---- & ---- & ---- & 1.00 & 0.05 \\
$\mathrm{Cd}$ & ------ & ---- & ---- & --- & -- & 1.00 \\
\hline$* \mathrm{p}<0.01 ; * \mathrm{p}<0.05$ & & & & &
\end{tabular}

Metal concentrations in sediment are show in Figure 2. Normalized data (Fig. 2a) show that concentrations tend to increase towards the channel mouth, which is fairly evident for $\mathrm{Zn}, \mathrm{Cu}$ and $\mathrm{Cd}$. For $\mathrm{Zn}$, there are significant differences $(\mathrm{p}<0.01)$ between the upstream $(\mathrm{Z}, \mathrm{A})$ and downstream stations $(\mathrm{G}, \mathrm{P})$. For the other two metals there are very high, significant $(p<0.01)$ peaks at site $G$ for $\mathrm{Cu}$ and site $\mathrm{P}$ for $\mathrm{Cd}$, which suggests local inputs of these metals. No overall trend was observed for $\mathrm{Fe}$ and $\mathrm{Pb}$ normalized concentrations, which remain more or less constant along the channel. Compared with the data in Figure $2 b$, the low levels of $\mathrm{Al}$ and $\mathrm{Fe}$ in station $\mathrm{G}$ indicate coarse sediment. According to reference values given by MacDonald et al. (1996) (Fig. 2) the study channel is very polluted with $\mathrm{Cu}$ (values $4 \mathrm{x}$ higher than the Probable Effects Level - PEL) and slightly polluted with $\mathrm{Zn}$ and $\mathrm{Pb}$ (values slightly higher in relation to Threshold Effects Level - TEL). Cd is the only metal whose values do not represent a biological risk.

\section{Metal in worm tissues}

Metal levels in $M$. sanguinea follow a similar pattern as that observed in the sediment (Fig. 3). Worms accumulate significantly $(\mathrm{p}<0.01)$ more $\mathrm{Zn}$, 

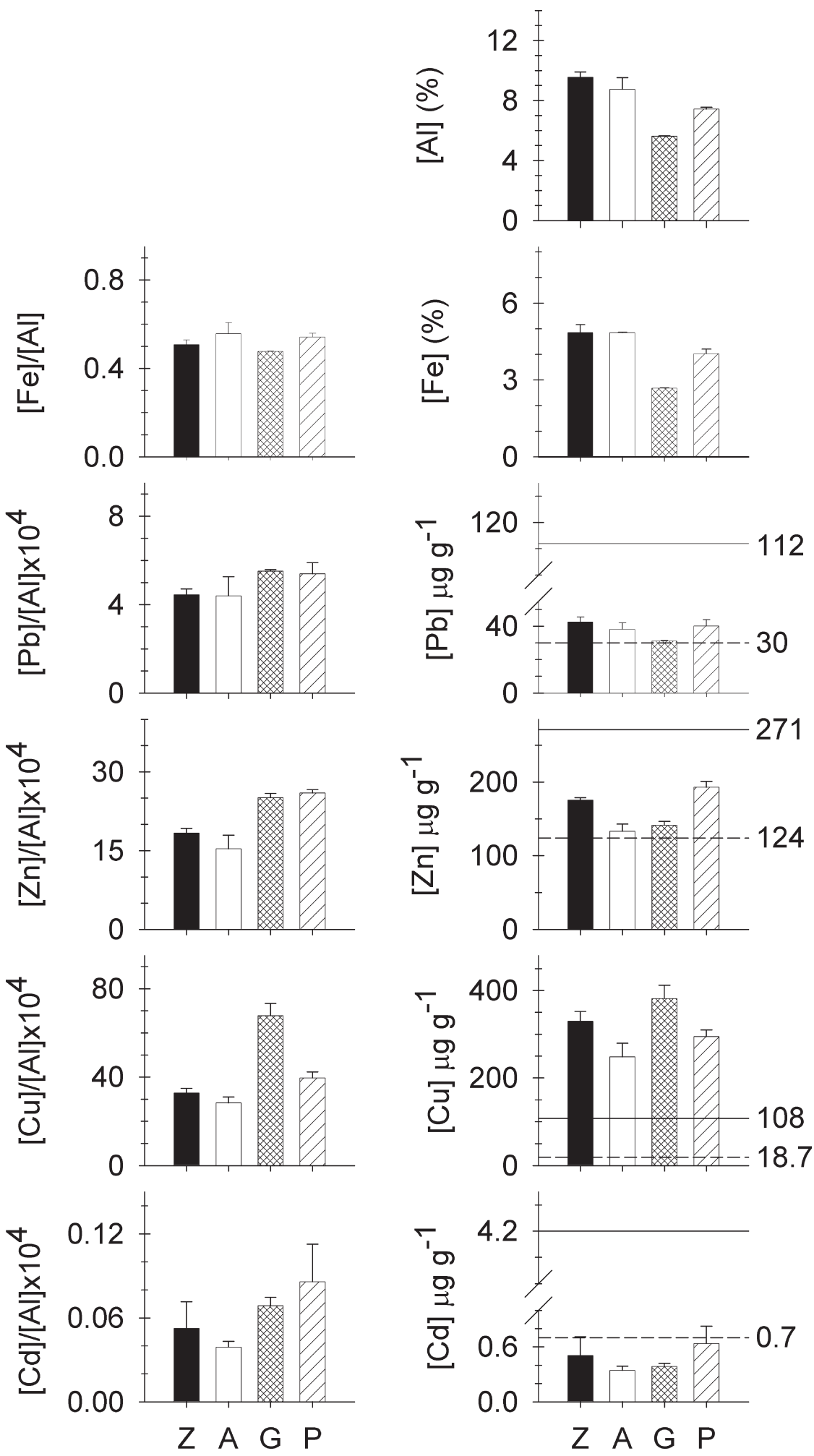

A

\section{sampling stations}

Fig. 2. - Metal concentrations ([Al], [Fe]\% and [Zn], [Cu], [Cd] $\mu \mathrm{g} \mathrm{g}^{-1}$ dry weight \pm s.d.) in the top $5 \mathrm{~cm}$ of sediment (n =3 samplings at each station) in Águas de Moura channel. s.d.- standard deviation. (A) normalized metal concentrations to Al; (B) non-normalized metal concentrations. Sediment quality guidelines for Florida Coastal waters (MacDonald et al., 1996): _ _ _ T.E.L. (threshold effects level);

P.E.L. (probable effects level) 

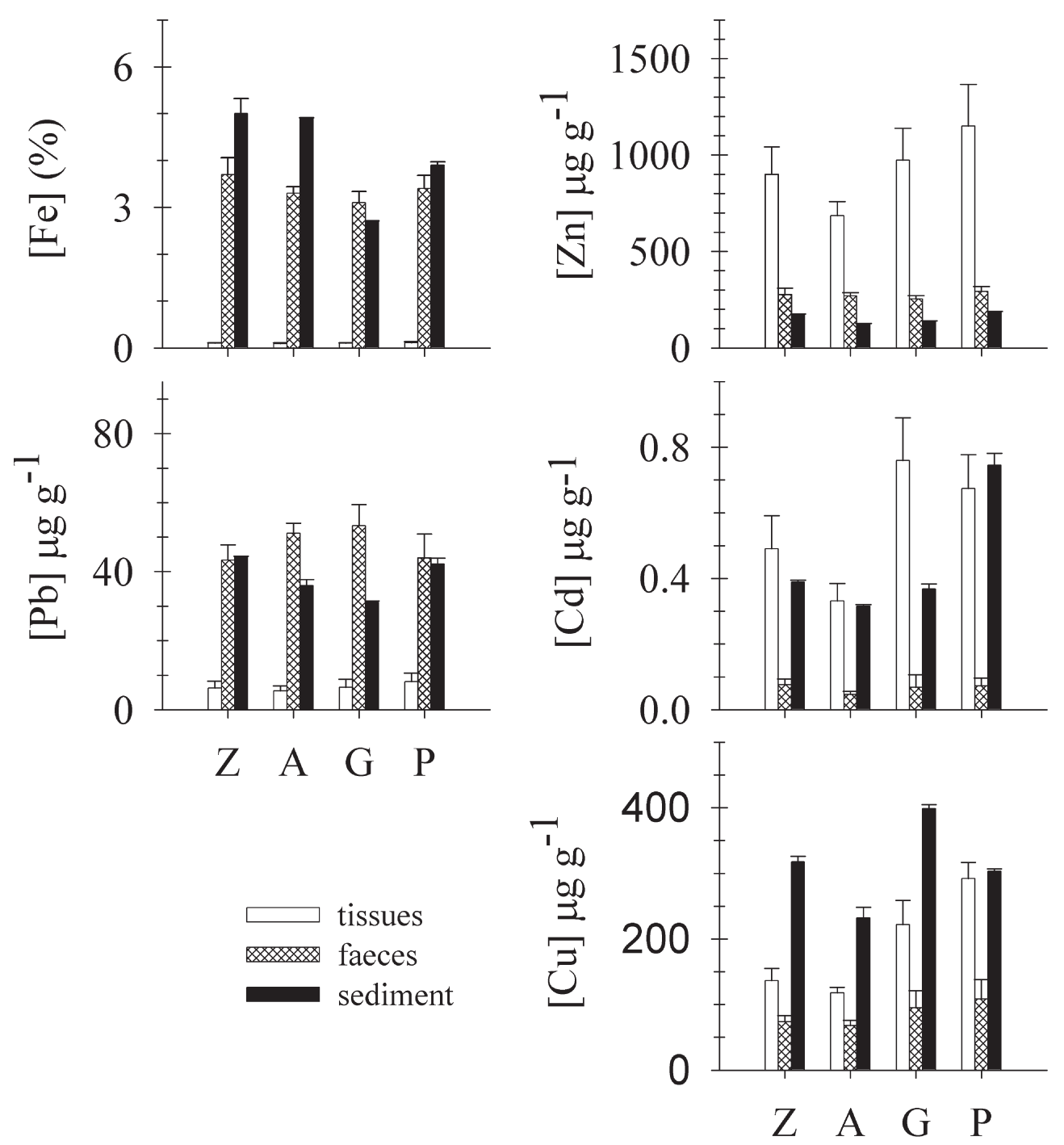

\section{sampling sites}

FIG. 3. - Relationships between average concentrations of $\mathrm{Fe}, \mathrm{Zn}, \mathrm{Cu} . \mathrm{Pb}$ and $\mathrm{Cd}\left(\mu \mathrm{g} \mathrm{g}{ }^{-1}\right.$ dry weight) in sediment ( $\left.\mathrm{n}=12\right)$, worm tissues and faeces ( $\mathrm{Z}=780 \mathrm{w}$.; $\mathrm{A}=680 \mathrm{w}$.; $\mathrm{G}=660 \mathrm{w}$.; $\mathrm{P}=660 \mathrm{w}$.) in sampling stations. $\mathrm{w}$ - worms

$\mathrm{Cu}$, and $\mathrm{Cd}$ in sites near the channel mouth. Analyzed metals can be characterized into two groups with different behaviours: $\mathrm{Fe}$ and $\mathrm{Pb}$ are excreted and $\mathrm{Zn}, \mathrm{Cu}$ and $\mathrm{Cd}$ are accumulated. In spite of the high excretion of $\mathrm{Fe}$ and $\mathrm{Pb}$, these metals are still highly concentrated in tissues (Table 5). Zn, $\mathrm{Cu}$ and $\mathrm{Cd}$ are definitely accumulated. However, the $\mathrm{Cu}$ behaviour suggests that there is a degree of adaptation, which and it is not surprising in view of the very high concentrations found in sediments to which this population is exposed. Greater differences between sampling sites occurred in station Garças $(\mathrm{G})$ where $\mathrm{Fe}$ concentrations in sediments were low ( $\mathrm{Z}=5 \% ; \mathrm{A}=4.9 \% ; \mathrm{G}=2.7 \% ; \mathrm{P}=4 \%$ )
(Fig. 4). Zn and $\mathrm{Cd}$ have the largest bioaccumulation factor (BAF - ratio between metal concentration in tissue and sediment $\left.\left[\mathrm{Me}_{t}\right] /\left[\mathrm{Me}_{s}\right]\right)$ in site $\mathrm{G}$ $\mathrm{p}<0.05)$ and the significant increase in $\mathrm{Cu}$ at station $\mathrm{P}(\mathrm{p}<0.01)$ doesn't coincide with the high sediment level found in station $\mathrm{G}$.

\section{Influence of body weight on metal accumulation and excretion}

The average metal concentration in each of the weight classes represented in Figure 5, shows that $\mathrm{Fe}, \mathrm{Pb}$ and $\mathrm{Zn}$ are influenced by the worm's weight, 
TABLE 5. - Metal concentration ( $\mu \mathrm{g} \mathrm{g} \mathrm{g}^{-1}$ d.w.) averaged over the whole populations and standard deviation ( \pm sd) in Marphysa sanguinea (MS) compared with metal concentrations in Arenicola marina (AM); Nereis diversicolor (ND); Nereis virens (NV); Heteromastus filiformes (HF) and Eurythoe complanata (EC) in several polluted estuary environments. The $95 \%$ confidence intervals are shown in brackets; $(\%$ value); nd, not determined.

\begin{tabular}{|c|c|c|c|c|c|c|c|c|}
\hline Estuaries & Area & $\mathrm{Fe}$ & $\mathrm{Zn}$ & $\begin{array}{c}\text { Metals } \\
\mathrm{Cu}\end{array}$ & $\mathrm{Pb}$ & $\mathrm{Cd}$ & $\begin{array}{l}\text { Polychaete } \\
\text { species }\end{array}$ & References \\
\hline Sado estuary & $\begin{array}{lr}\text { Portugal } & 9 \\
& (86\end{array}$ & $\begin{array}{l}944.7 \pm 192.2 \\
863.6-1025.9)\end{array}$ & $\begin{array}{c}927 \pm 224.5 \\
(832.4-1021.9)\end{array}$ & $\begin{array}{c}192.1 \pm 75 \\
(160.5-223.8)\end{array}$ & $\begin{array}{c}6.6 \pm 2.2 \\
(5.7-7.5)\end{array}$ & $\begin{array}{c}0.56 \pm 0.19 \\
(0.48-0.65)\end{array}$ & MS & this work \\
\hline Barents sea & & nd & $47 \pm 12$ & $6.8 \pm 1.8$ & $0.8 \pm 0.3$ & $0.34 \pm 0.27$ & $\mathrm{AM}$ & Zauke et al., 2003 \\
\hline Dulas bay & Wales & nd & $544 \pm 30$ & $3365 \pm 422$ & $1.48 \pm 0.27$ & nd & & Zhou et al., 2003 \\
\hline Orwell & England & nd & 222 & $\begin{array}{l}35.7 \\
661017\end{array}$ & 3.26 & 0.50 & $\mathrm{ND}$ & Wricht and Mocon 1000 \\
\hline Orwell & England & nd & $\begin{array}{c}191-269 \\
163 \\
142-170\end{array}$ & $\begin{array}{c}6.61-91.7 \\
28.5 \\
20.3-41.7\end{array}$ & $\begin{array}{c}0.51-9.81 \\
1.49 \\
1.41-1.57\end{array}$ & $\begin{array}{c}0.16-1.23 \\
0.86 \\
0.58-1.17\end{array}$ & $\begin{array}{l}\mathrm{ND} \\
\mathrm{AM}\end{array}$ & $\begin{array}{l}\text { Wright and Mason, } 1999 \\
\text { “ }\end{array}$ \\
\hline $\begin{array}{l}\text { Mazatlán Bay } \\
\text { Several estuaries }\end{array}$ & $\begin{array}{l}\text { Mexico } \\
\text { Galizia }\end{array}$ & $\begin{array}{l}\text { nd } \\
\text { nd }\end{array}$ & $\begin{array}{c}213 \pm 208 \\
131\end{array}$ & $\begin{array}{c}3.9 \pm 1.3 \\
44\end{array}$ & $\begin{array}{c}15.3 \pm 3.5 \\
7\end{array}$ & $4.9 \pm 1.3$ & EC & Méndez and Páez-Osuna, 1998 \\
\hline & & & $(18-507)$ & $(4-724)$ & $(7.7-27)$ & nd & ND & Carral et al., 1995 \\
\hline Bou Regreg & Morocco 5 & $5430-9224$ & $555-654$ & 53 & nd & nd & ND & Cheggour et al., 1990 \\
\hline Tamar & England & 592 & 141 & 21.5 & nd & nd & NV & Bryan and Gibbs, 1980 \\
\hline Kyeonggi Bay & South Korea & ea $0.4^{\star}$ & 47 & 449 & 8.9 & 0.11 & $\mathrm{HF}$ & \\
\hline
\end{tabular}

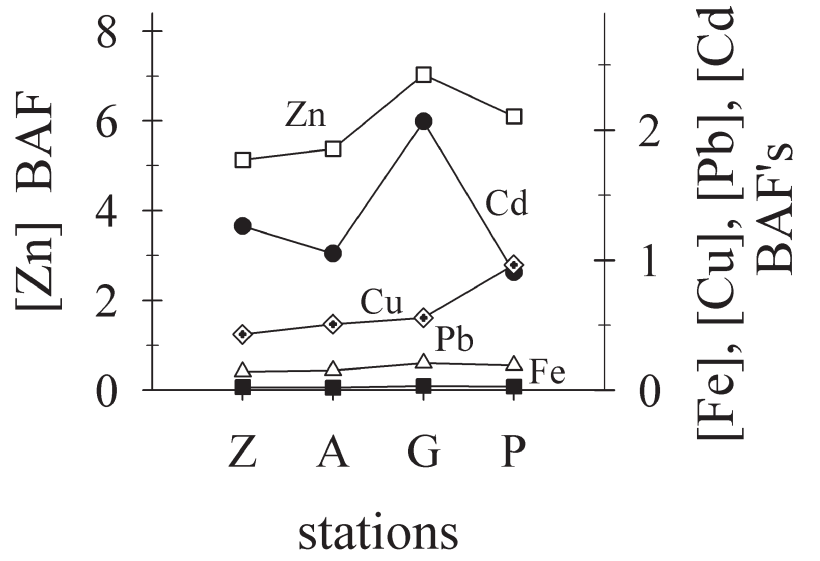

Fig. 4. - Bioaccumulation factor (ratio between metal concentration in tissue $[\mathrm{Me}]_{\mathrm{t}}$ and sediment $\left.[\mathrm{Me}]_{\mathrm{s}}-\mathrm{BAF}\right)$ in the $M$. sanguinea population in Águas de Moura Channel.

with a tendency to an inverse relationship. The effect of body weight on bioaccumulation was examined with a multidimensional scaling analysis. Two dimensions were retained according to the Scree-Plot criterion (stress- $\mathrm{I}=3 \mathrm{E}^{-2} ; \mathrm{RSQ}=0.99$ ). Figure 6 shows that some of the wet-weight classes have a distinct metal composition. We can also see a clear distinction between upstream $(\mathrm{Z}, \mathrm{A})$ and downstream sta- tions $(\mathrm{G}, \mathrm{P})$. This analysis was refined with a non-hierarchical K-means clusters analysis (Table 6). The summarized data clearly show the largest concentrations of all metals in the small wet-weight classes, and also confirm that the highest tissue-metal concentrations are found in the downstream stations $(\mathrm{G}$, $\mathrm{P}$ ): Cluster 7 (class $\mathrm{P}_{1}$ ) (values $>1$ for all metals). Cluster $8\left(\mathrm{P}_{2}, \mathrm{P}_{3}\right.$ and $\left.\mathrm{P}_{4}\right)$ also shows positive values $\leq 1$, as well as clusters $6\left(\mathrm{G}_{1}\right), 10\left(\mathrm{G}_{4}\right)$ and $1\left(\mathrm{Z}_{1}\right)$. The F-ANOVA also shows that $\mathrm{Zn}(\mathrm{F}=23.9)$ and $\mathrm{Cd}$ $(\mathrm{F}=21)$ are the metals with most influence on cluster discrimination. However, $\mathrm{F}$ tests should be used only for descriptive purposes because clusters have been chosen to maximize differences among classes in different clusters. For this reason the error probabilities associated with these results were evaluated through a two discriminant analysis, and the existence of collinear relationships was tested. All metals show normal distributions ( $\mathrm{p}>0.05$ ) for all classes, which is also confirmed by the variance-covariance homogeneity (Table 7). In the first method (Wilks' lambda), although the results show that only $\mathrm{Pb}$ has significantly discriminant power ( $p=0.001)$, the stepwise analysis extracted two functions retaining $\mathrm{Fe}$

TABLE 6. - Wet-weight class classification for the method K-means with $\mathrm{K}=11$ clusters and one-way ANOVA for each metal. The weight class corresponding to the clusters is shown in brackets.

\begin{tabular}{|c|c|c|c|c|c|c|c|c|c|c|c|c|c|}
\hline & $\begin{array}{c}1 \\
\left(Z_{1}\right)\end{array}$ & $\left(\mathrm{Z}_{2}, \mathrm{Z}_{3}, \mathrm{G}_{5}, \mathrm{P}_{5}\right)$ & $\begin{array}{c}3 \\
\left(\mathrm{~A}_{6}\right)\end{array}$ & $\begin{array}{c}4 \\
\left(\mathrm{P}_{6}\right)\end{array}$ & $\left(\mathrm{Z}_{4}, \mathrm{Z}_{5}, \mathrm{~A}_{1}, \mathrm{~A}_{2}\right)$ & $\begin{array}{c}6 \\
\left(\mathrm{G}_{1}\right)\end{array}$ & $\begin{array}{c}7 \\
\left(\mathrm{P}_{1}\right)\end{array}$ & $\left(\begin{array}{c}8 \\
\left(\mathrm{P}_{2}, \mathrm{P}_{3}, \mathrm{P}_{4}\right)\end{array}\right.$ & $\begin{array}{c}9 \\
\left(\mathrm{~A}_{3}, \mathrm{~A}_{4}, \mathrm{~A}_{5}\right)\end{array}$ & $\begin{array}{c}10 \\
\left(\mathrm{G}_{4}\right)\end{array}$ & $\left(\mathrm{Z}_{6}, \mathrm{G}_{2}, \mathrm{G}_{3}, \mathrm{G}_{6}\right)$ & F & $\mathrm{P}$ \\
\hline $\mathrm{Fe}$ & 1.08 & 0.11 & -2.34 & -1.15 & 0.003 & -0.04 & 2.26 & 1.02 & 0.08 & 0.44 & -0.98 & 9.72 & .000 \\
\hline $\mathrm{Zn}$ & 0.93 & 0.003 & -1.15 & 0.27 & -0.79 & 1.52 & 2.56 & 1.02 & -1.38 & 0.55 & -0.26 & 23.9 & .000 \\
\hline $\mathrm{Cu}$ & -0.36 & -0.05 & -0.91 & 1.29 & -0.89 & 0.25 & 1.71 & 1.38 & -1.09 & 1.36 & -0.16 & 7.54 & .001 \\
\hline $\mathrm{Pb}$ & 1.55 & -0.58 & -1.14 & 0.20 & -0.15 & 2.00 & 2.90 & 0.50 & -0.92 & -0.69 & -0.36 & 14.35 & .000 \\
\hline $\mathrm{Cd}$ & -0.79 & 0.17 & -1.52 & -0.33 & -0.99 & 1.73 & 1.01 & 0.76 & -1.16 & 1.98 & 0.55 & 20.97 & .000 \\
\hline
\end{tabular}


(A)
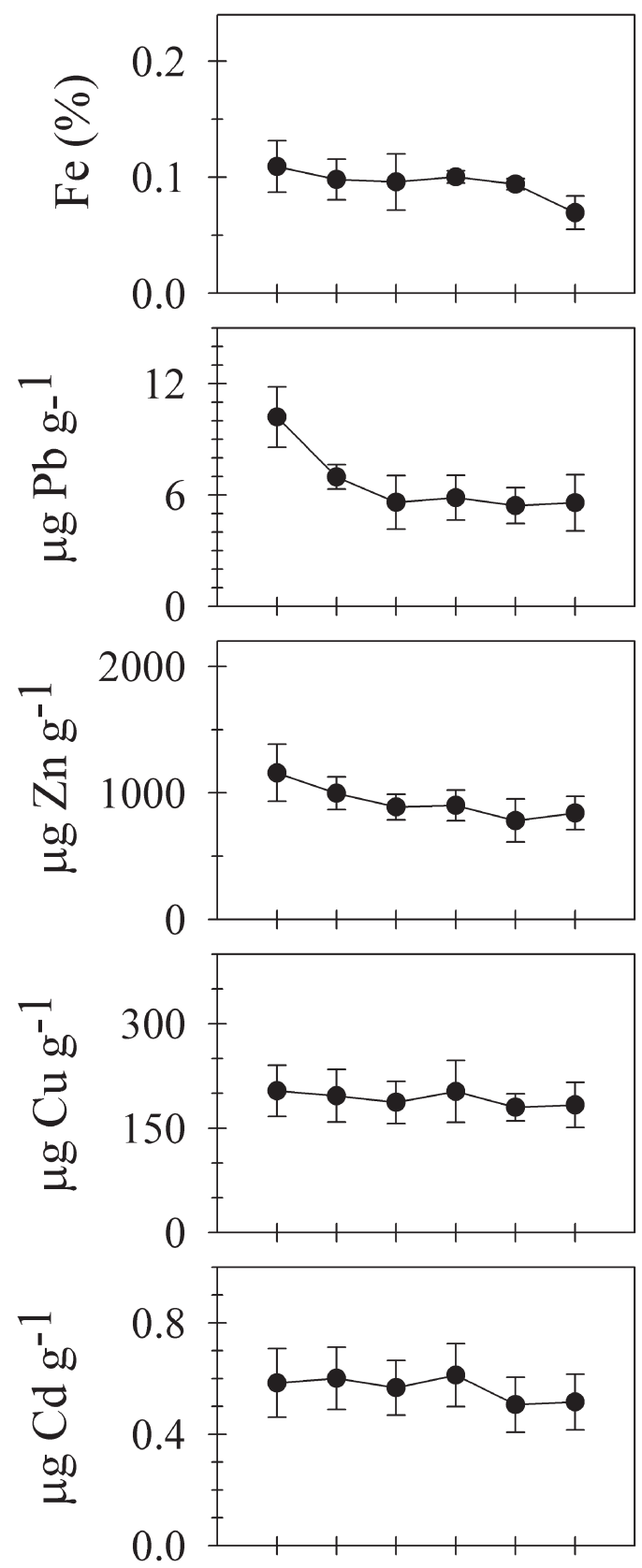

C1 C2 C3 C4 C5 C6
(B)
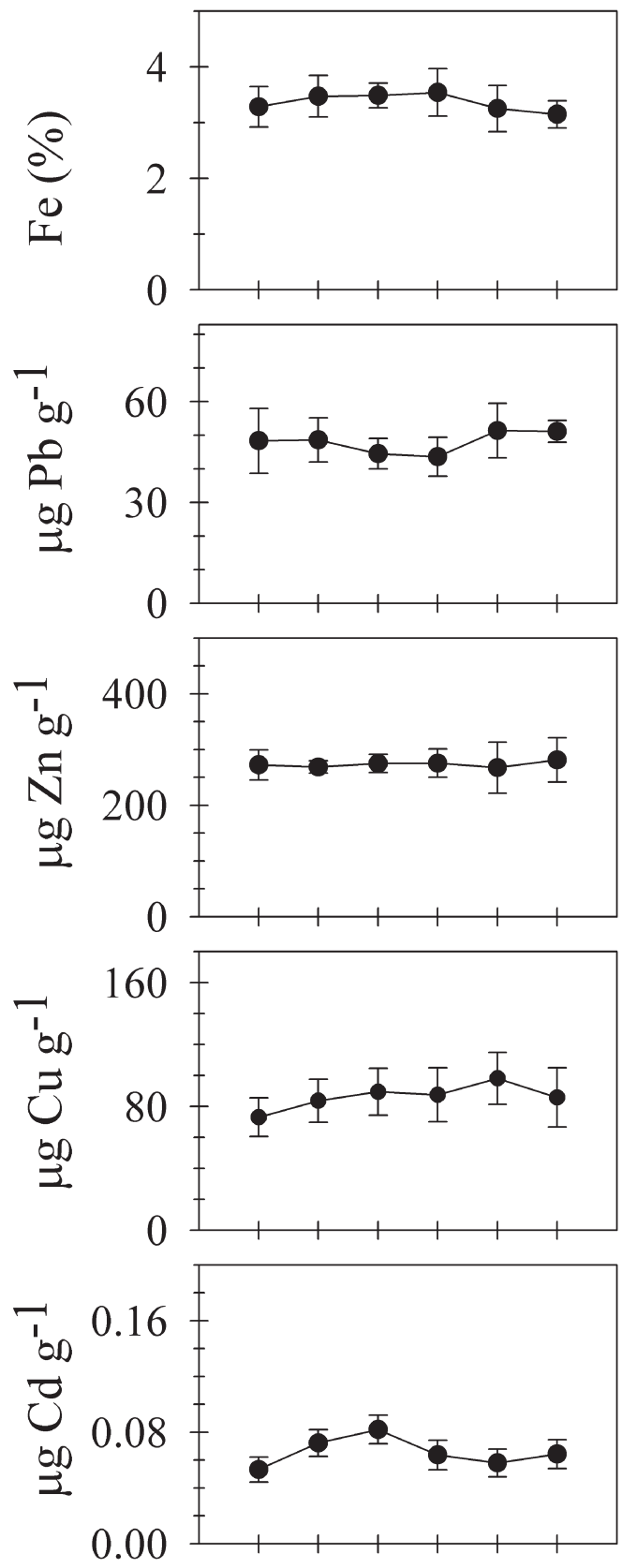

C1 C2 C3 C4 C5 C6

\section{wet weight class}

Fig. 5. - Averaged metal concentrations (\% $\%$ s.d. (Fe) and $\mu \mathrm{g} \mathrm{g} \mathrm{g}^{-1}$ d.w. \pm s.d. ( $\mathrm{Pb}, \mathrm{Zn}, \mathrm{Cu}$ and $\mathrm{Cd}$ ) in each wet-weight class and in whole worm tissues (A) and faeces (B) along Águas de Moura channel. s.d. - standard deviation; $\mathrm{C}_{1}[0.5-1]_{\mathrm{g}} ; \mathrm{C}_{2}[1-1.5]_{\mathrm{g}} ; \mathrm{C}_{3}[1.5-2]_{\mathrm{g}} ; \mathrm{C}_{4}[2-2.5]_{\mathrm{g}} ; \mathrm{C}_{5}[2.5-3]_{\mathrm{g}}$; $\mathrm{C}_{6}[3-3.5]_{\mathrm{g}}$ wet-weight; $\mathrm{nC}_{1}=234 ; \mathrm{nC}_{2}=550 ; \mathrm{nC}_{3}=731 ; \mathrm{nC}_{4}=650 ; \mathrm{nC}_{5}=407 ; \mathrm{nC}_{6}=208$

as statistically significant, although the discriminant power is questionable $(\mathrm{p}=0.06)$. Function 1 , defined essentially by $\mathrm{Pb}$, explains $76 \%$ of the variability and discriminates all the wet-weight classes significantly $\left(\wedge=0.20 ; \chi^{2}(10)=30.57 ; \mathrm{p}=0.001\right)$. However, the second retained function, defined by $\mathrm{Fe}$, does not discriminate all the classes significantly $(\Lambda=0.61$; $\left.\chi^{2}(4)=9.44 ; p=0.05\right)$. In order to assure that the selected metals $(\mathrm{Pb}$ and $\mathrm{Fe})$ are in fact important, a new analysis was carried out using $\mathrm{DM}^{2}$. In this method 


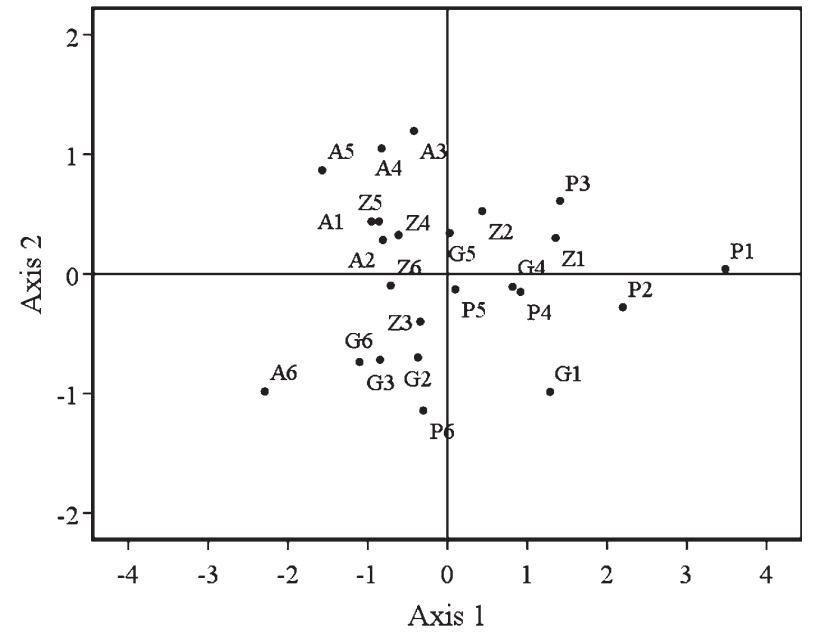

FIG. 6. - Multidimensional scaling (MDS) - two-dimensional map - of the metal composition in each wet weigh class along Águas de Moura channel (Stress $\left.=3 \mathrm{E}^{-2} ; \mathrm{RSQ}=0.99\right)$. Letters refer to the sampling site and numbers $(1-6)$ refer to the weight classes.

TABLE 7. - Test null hypothesis of equal population covariance matrices in the two methods used: Wilks' lambda $(\wedge)$ and the Mahalanobis distance $\left(\mathrm{DM}^{2}\right)$

\begin{tabular}{lcc}
\hline & Wilkis' & Mahalanobis distance \\
\hline Box's M & 16.97 & 4.97 \\
F Approx. & 0.80 & 0.88 \\
Sig. & 0.67 & 0.49 \\
\hline
\end{tabular}

only $\mathrm{Pb}$ was selected and the function extracted discriminates all the weight classes significantly $(\wedge$ $\left.=0.353 ; \chi^{2}(5)=20.9 ; p=0.001\right)$. Table 8 presents the classification statistics of wet-weight classes with the respective classification functions generated by these two analyses. In the first one, $45.8 \%$ of the classes were correctly classified, against $33.3 \%$ in the second one. Comparing the two methods, we can see that $\mathrm{Pb}$ without the influence of $\mathrm{Fe}$, in spite of its weak performance, classified the two small classes very well $\left(\mathrm{C}_{1}\right.$ and $\mathrm{C}_{2}-75 \%$ for both $)$. When the two metals are associated they perform better for the largest classes $\left(\mathrm{C}_{4}\right.$ to $\left.\mathrm{C}_{6}\right)$. The smallest class $\left(\mathrm{C}_{1}\right)$ was always well classified with the two methods.
TABLE 9. - Kruskal Wallis Test between metal concentrations in each wet-weight class; Grouping Variable: Classes.

\begin{tabular}{|c|c|c|c|c|c|c|}
\hline \multirow{3}{*}{$\mathrm{Fe}$} & \multicolumn{5}{|c|}{ Sum of Squares df Mean Square F } & $\mathrm{p}$ \\
\hline & Between classes & 76.87 & 5 & 15.37 & 0.33 & 0.89 \\
\hline & Within classes & 848. & 18 & & & \\
\hline & Total & 925.50 & 23 & & & \\
\hline \multirow[t]{3}{*}{$\mathrm{Zn}$} & Between classes & 495 & 5 & 99 & 2.72 & 0.05 \\
\hline & Within classes & 654.50 & 18 & 36.36 & & \\
\hline & Total & 1149.50 & 23 & & & \\
\hline \multirow[t]{3}{*}{$\mathrm{Cu}$} & Between classes & 42.37 & 5 & 8.47 & 0.14 & 0.98 \\
\hline & Within classes & 1104.12 & 18 & 61.34 & & \\
\hline & Total & 1146.50 & 23 & & & \\
\hline \multirow[t]{3}{*}{$\mathrm{Pb}$} & Between classes & 587.50 & 5 & 117.50 & 3.84 & 0.01 \\
\hline & Within classes & 550 & 18 & 30.56 & & \\
\hline & Total & 1137.50 & 23 & & & \\
\hline \multirow[t]{3}{*}{$\mathrm{Cd}$} & Between classes & 84.25 & 5 & 16.85 & 0.28 & 0.91 \\
\hline & Within classes & 1063.75 & 18 & 59.1 & & \\
\hline & Total & 1148 & 23 & & & \\
\hline
\end{tabular}

The results obtained with the Kruskal-Wallis analysis (Table 9) confirm the results achieved for $\mathrm{Pb}$ and also show that $\mathrm{Zn}$ is an important element in weight class differentiation.

\section{DISCUSSION}

\section{Metals in sediment}

Metal concentrations in sediment were generally higher at the entrance of the channel as has been previously described by Cortesão (2003). The high correlations obtained between $\mathrm{Fe} / \mathrm{Al}$ and $\mathrm{Pb} / \mathrm{Al}$ suggest that $\mathrm{Fe}$ and $\mathrm{Pb}$ are closely associated with aluminosilicates. Moreover, inside this fine fraction the close relationship between $\mathrm{Fe}$ and $\mathrm{Pb}$ shows that $\mathrm{Pb}$ is mainly associated with $\mathrm{Fe}$ oxyhydroxides $(\mathrm{FeOOH})$, which also have a great capacity to retain trace metals like $\mathrm{Cd}$ and $\mathrm{Cu}$. In fact the largest differences between stations occurred where $\mathrm{Fe}$ concentrations were low. The $[\mathrm{Me}] / \mathrm{Al}$ ratio for $\mathrm{Zn}$ and $\mathrm{Cd}$ increased from upstream to downstream along Águas de Moura Channel, which reflects the

TABLE 8. - Original classification results used in the discriminant analysis with the two methods: Wilks' lambda $(\wedge)$ and the Mahalanobis distance. WWC, wet-weight classes.

\begin{tabular}{|c|c|c|c|c|c|c|c|c|c|c|c|c|c|c|}
\hline \multirow[b]{2}{*}{ WWC } & \multirow{2}{*}{\multicolumn{6}{|c|}{$\begin{array}{c}\text { Wilks' } \wedge \\
\text { Predicted Group Membership }\end{array}$}} & \multicolumn{8}{|c|}{$\begin{array}{c}\text { Mahalanobis distance } \\
\text { Predicted Group Membership }\end{array}$} \\
\hline & & & & & & 6 & Total $(\%)$ & 1 & 2 & 3 & 4 & 5 & 6 & $\operatorname{Total}(\%)$ \\
\hline 1 & $3(75)$ & $1(25)$ & $0(0)$ & $0(0)$ & $0(0)$ & $0(0)$ & $4(100)$ & $3(75)$ & $1(25)$ & $0(0)$ & $0(0)$ & $0(0)$ & $0(0)$ & $4(100)$ \\
\hline 2 & $0(0)$ & $2(50)$ & $0(0)$ & $1(25)$ & $0(0)$ & $1(25)$ & $4(100)$ & $0(0)$ & $3(75)$ & $0(0)$ & $1(25)$ & $0(0)$ & $0(0)$ & $4(100)$ \\
\hline 3 & $0(0)$ & $0(0)$ & $0(0)$ & $2(50)$ & $1(25)$ & $1(25)$ & $4(100)$ & $0(0)$ & $1(25)$ & $0(0)$ & $1(25)$ & $2(50)$ & $0(0)$ & $4(100)$ \\
\hline 4 & $0(0)$ & $1(25)$ & $0(0)$ & $2(50)$ & $1(25)$ & $0(0)$ & $4(100)$ & $0(0)$ & $1(25)$ & $0(0)$ & $0(0)$ & $3(75)$ & $0(0)$ & $4(100)$ \\
\hline 5 & $0(0)$ & $1(25)$ & $1(25)$ & $1(25)$ & $1(25)$ & $0(0)$ & $4(100)$ & $0(0)$ & $0(0)$ & $0(0)$ & $2(50)$ & $2(50)$ & $0(0)$ & $4(100)$ \\
\hline 6 & $0(0)$ & $1(25)$ & $0(0)$ & $0(0)$ & $0(0)$ & $3(75)$ & $4(100)$ & $0(0)$ & $1(25)$ & $0(0)$ & $1(25)$ & $2(50)$ & $0(0)$ & $4(100)$ \\
\hline
\end{tabular}


influence of anthropogenic sources. Higher levels of $\mathrm{Cu}, \mathrm{Zn}$ and $\mathrm{Cd}$ occurred at downstream stations ( $\mathrm{G}$ and $\mathrm{P}$ ), evidencing the importance of Sado river as a metal source for the estuary (Cortesão, 2003; Caeiro et al., 2005b).

Considering the potential toxicity of sediments in the study area, reference values given by MacDonald et al. (1996) suggest that there is a physiological Cu-adaptation in Marphysa sanguinea. In fact all analyzed specimens were in apparently healthy condition considering animal activity and the gametogenic development in most of them. High Cu-levels (200-2000 $\mu \mathrm{g} \mathrm{g}^{-1}$ dry weight) in the sediment are known to be toxic to aquatic animals including meioand macrofauna (Morrisey et al., 1996; Austen and Somerfield, 1997).

\section{Metals in worm tissues}

Comparing the mean metal-concentration in the $M$. sanguinea population in the studied channel with the concentrations in other polychaete species from other estuarine environments, the present values can be considered relatively high for $\mathrm{Fe}, \mathrm{Zn}, \mathrm{Cu}$ and $\mathrm{Pb}$, and moderate for $\mathrm{Cd}$. The results obtained for $\mathrm{Fe}$ and $\mathrm{Pb}$ could be explained by low availability. Most of the $\mathrm{Fe}$ is in an unavailable form, as Fe-hydroxides or sulphides, but it seems that a substantial amount is still available to be absorbed (Table 5), which is suggested by the high $\mathrm{Fe}$ excretion superior to sediment levels $(1.4 \pm 0.09)$ in station $\mathrm{G}$. The high $\mathrm{Pb}$ excretions, superior to $\mathrm{Pb}$ sediment levels in all stations $(1.3 \pm 0.2)$, suggest that although there is very low availability, there is some accumulation and eventually other sources of $\mathrm{Pb}$ intake. The significant correlations between $\mathrm{Fe}$ and $\mathrm{Pb}$ also suggest that the Fe concentration in sediment may influence the availability of $\mathrm{Pb}$ by influencing the physicochemical form of sediment-bound $\mathrm{Pb}$. Luoma and Bryan (1978) found that $\mathrm{Fe}$ influences $\mathrm{Pb}$ availability in Scrobicularia plana. In addition, the significant differences that occurred between station $\mathrm{G}$, where Fe concentrations in sediments were low, and the other stations, suggest that Fe influences the availability of the other metals.

It is well known that $\mathrm{Zn}, \mathrm{Cu}$ and $\mathrm{Cd}$ are accumulated in Hediste (syn. Nereis) diversicolor and other annelids in agreement with the metal concentrations in the sediment (Berthet et al., 2003; Nipper and Carr, 2003). The degree to which these metals accumulate in $M$. sanguinea varied considerably. $\mathrm{Zn}$ showed the highest accumulation. At all sampling stations, $\mathrm{Zn}$ concentrations in $M$. sanguinea exceeded the concentrations in the sediments $(5.8 \pm 1.4)$, with an average $\mathrm{BAF}=6 \pm 1.2$, which suggests sequestration or other uptake sources. For example, in station $\mathrm{G}$ the tissue concentration reached up to seven times the sediment values. $\mathrm{Zn}$ concentrations found here (560 to $1502 \mu \mathrm{g} \mathrm{Zn} \mathrm{g}^{-1}$ ) were much higher in comparison to those presented in the cited literature. In contrast, $\mathrm{Cd}$ levels in $M$. sanguinea approaches those in the sediments at all surveyed sites except at station $G$ (1.6 \pm 0.3$)$, with an average BAF of $1.3 \pm 0.5$. The low excretion obviously suggests accumulation. Cd values obtained in this work are comparable with those of $N$. diversicolor in Table 5. In light of the very high concentrations in sediments referred to previously and the accumulation under certain limits, the results for $\mathrm{Cu}$ show the existence of an obvious adaptation. In fact, the values obtained in this study (102 to $320 \mu \mathrm{g} \mathrm{Cu} \mathrm{g}^{-1}$ ) are relatively high in comparison with those presented in Table 5. These very high $\mathrm{Cu}$ levels, especially in sediments, suggest that there is some kind of regulation. However, bioaccumulation is the result of a complex interactivity between sediment characteristics and animal physiology and therefore factors such as animal size need to be considered.

\section{Influence of body weight on metal accumulation and excretion}

The bioaccumulation results obtained for Marphysa populations along Águas de Moura Channel previously discussed, indicate that $\mathrm{Zn}, \mathrm{Cu}$ and $\mathrm{Cd}$ bioaccumulation does not seem to be supported when body weight is considered. In fact, $\mathrm{Cu}$ and $\mathrm{Cd}$ concentrations are not higher in bigger specimens while $\mathrm{Pb}, \mathrm{Zn}$ and $\mathrm{Fe}$ concentrations tend to have a negative relationship with body size. Is there sizedependence for all metals including $\mathrm{Cu}$ and $\mathrm{Cd}$ ? The observed decline in some metal body burdens in the bigger worms could be a result of growth-dilution. In fact, this polychaete is considerably large and has a short life cycle (1.4 years) (Castro, 1993), and it is very probable that the metal concentration in tissues is influenced by its fast growth. Previous works on growth rates of polychaetes, especially in $N$. diversicolor (Fidalgo e Costa 2001), Nereis virens (Olive et al., 1991), Arenicola marina (De Wilde and Berghuis, 1979; Farke and Berghuis, 1979) and M. sanguinea (Castro, 1993) revealed a significantly 
higher rate in the first months. According to Ahrens et al. (2001), the prolonged resident time of ingested food in juveniles of Nereis succinea, allied with their digestive chemistry, facilitates desorption and subsequently the increased uptake of sediment-bound contaminants. However, assuming that most metals are sequestered in hard structures and epithelial surfaces (such as jaws, cuticle and the gut lining) then boundmetals would increase at a slower rate than weight (which scales with an exponent of $\mathrm{x}^{3}$ ) compared to surfaces $\left(\mathrm{x}^{2}\right)$. This could explain why bigger worms have relatively less metals in their tissues, i.e. it is mostly in hard parts, which are associated with total surface area. The very high $\mathrm{Zn}$ levels provide evidence of sequestration within the animals. Bryan and Gibbs (1979) proposed that the jaws might serve as a metal-sink, sequestering toxic levels of $\mathrm{Zn}$ absorbed from the sediment away from the living tissue $(1.5 \%$ of the dry weight and $70-80 \%$ of the total metal content in Nereis jaws). They also demonstrated that $\mathrm{Zn}$ concentrations fall very significantly with increasing size, and significant concentrations of other metals, including $\mathrm{Fe}$, are also present. Further observations (Lichtenegger et al., 2003, Broomell et al., 2006, 2007) demonstrated that Zn levels in Nereis jaws were high, regardless of the environmental context, which led to the hypothesis that metals might contribute to their mechanical properties.

A complex jaw apparatus consisting of ventral mandibles and dorsal maxillae is characteristic of polychaetes of the Eunicidae family. The high levels of $\mathrm{Zn}$ and $\mathrm{Pb}$ in the smallest wet-weight classes of $M$. sanguinea can be related to the carbonate nature of the jaws (structures composed of calcium carbonate and/or scleroproteins (Paxton, 2006; Voss-Foucart et al., 1973).

The results obtained show that $\mathrm{Fe}$ influences large weight classes. The relatively high level of $\mathrm{Fe}$ in small worms possibly reflects the deposition of Fe-oxides on their exposed surfaces. The source of this Fe may be the overlying water or, more probably, the interstitial water found in the reduced subsurface sediments into which the irrigated burrows penetrate. The high $\mathrm{Fe}$ levels in the youngest $M$. sanguinea worms could also be the result of metabolic needs in view of the essential role of $\mathrm{Fe}$ in, for example, Marphysa haemoglobin. The absence of a clear relationship between $\mathrm{Cu}$ and $\mathrm{Cd}$ concentrations and body weight can be explained by physiological factors like reproductive maturation (Howard and Brown, 1983), copper regulation capacity (Mén- dez and Páez-Osuna, 1998), and specific metabolic needs. However, we found size-dependence for all the metals, including $\mathrm{Cu}$ and $\mathrm{Cd}$ (even though the $\mathrm{r}^{2}$ are lower).

In conclusion, the results obtained suggest: (1) Fe has a strong influence on metal availability, mainly for $\mathrm{Pb}$; (2) M. sanguinea is adapted to the high $\mathrm{Cu}$ and Fe levels in Àguas de Moura Channel; (3) the significant differences in $\mathrm{Zn}$ and $\mathrm{Pb}$ concentrations between the small weight classes $\left(\mathrm{C}_{1}\right.$ and $\left.\mathrm{C}_{2}\right)$ and larger ones $\left(\mathrm{C}_{3}\right.$ to $\left.\mathrm{C}_{6}\right)$ indicate that it is important to consider the worm's weight in environmental monitoring programmes. However, further investigations addressing other ecotoxicological aspects (e.g. metabolic routes involved in metal accumulation and excretion) are encouraged in order to confirm this suggestion and to reinforce the relevance of this species to be included in environmental monitoring programmes in Sado estuary.

\section{ACKNOWLEDGEMENTS}

This study forms a part of a large research programme T.P.A. (Tecnologias de Produção Aquícola) coordinated and financed by Q.C.A. III/med. 4/Programe MARE.

\section{REFERENCES}

Ahrens, M.J., J. Hertz, E.M. Lamoureux, G.R. Lopez, A.E. McElroy and B.J. Brownawell. - 2001. The effect of body size on digestive chemistry and absorption efficiencies of food and sedimentbound organic contaminants in Nereis succinea (Polychaeta). J. Exp. Mar. Bio. Ecol., 263: 185-209.

Austen, M.C. and P.J. Sommerfield. - 1997. A community level sediment bioassay applied to an estuarine metal gradient. Mar. Environ. Res., 43: 315-328.

Berthet, B., C. Mouneyrac, J.C. Amiard, C. Amiard-Triquet, Y. Berthelot, A. Le Hen, O. Mastain, P.S. Rainbow and B.D. Smith. - 2003. Accumulation and soluble binding of cadmium, cooper and $\mathrm{Zn}$ in the polychaete Hediste diversicolor from coastal sites with different trace metal bioavailability. Arch. Environ. Contam. Toxicol., 45: 468-478.

Broomell, C.C., M.A. Mattoni, F.W. Zok and J.H. Waite. - 2006. Critical role of zinc in hardening of Nereis jaws. J. Exp. Biol., 209: 3219-3225.

Broomell, C.C., R.K. Khan, D.N. Moses, A. Miserez, M.G. Pontin, G.D. Stucky, F.W. Zok and J.H. Waite. - 2007. Mineral minimization in nature's alternative teeth. J. R. Soc. Interface., 4: 19-31.

Bryan, G.W. and P.E. Gibbs. - 1980. Metals in Nereid polychaetes: the contribution of metals in the jaws to the total body burden. J. Mar. Biol. Assoc. UK., 60: 641-654.

Bryan, G.W. and P.E. Gibbs. - 1979. Zinc - a major inorganic component of Nereid polychaete jaws. J. Mar. Biol. Assoc. UK., 59: 969-973.

Cabeçadas, G., M.J. Brogueira and L. Cabeçadas. - 2000. Southern Portugal: the Tagus and Sado estuaries. In: C. Sheppard (ed.), Seas at the millennium: an environmental evaluation, pp. 151- 
165. Elsevier Science, Oxford.

Caeiro, S., M.H. Costa, P. Goovaerts and F. Martins. - 2005a. Benthic biotope index for classifying habitats in the Sado estuary. Mar. Environ. Res., 60: 570-593.

Caeiro, S., M.H. Costa, T.B. Ramos, F. Fernandes, N. Silveira, A. Coimbra, G. Medeiros and M. Painho - 2005b. Assessing heavy metal contamination in Sado estuary sediment: an index analysis approaching. Ecol. Indicators., 5: 151-169.

Carral, E., X. Puente, R. Villares and Carballeira. - 1995. Background heavy metals levels in estuarine sediments and organisms in Galizia (northwest Spain) as determined by modal analysis. Sci. Total Environ., 172: 175-188.

Castro, J.J. - 1993. Impacte da exploração comercial e estrutura, dinâmica e produção da população de Marphysa sanguinea Montagu (Anelida: Poliqueta) no estuário do Sado. Ph. D. thesis, Univ. Évora.

Cortesão, C. - 2003. Distribuição e reactividade do cádmio, cobre, crómio, níquel e cobalto no estuário do Sado. Ph. D. thesis, Univ. Lisboa.

De Wilde, P.A.W. and E.M. Berghuis. - 1979. Laboratory experiments on growth of juvenile lugworms, Arenicola marina. Netherlands J. Sea Res., 13(3/4): 487-502.

Diéz, G., M. Soto, L. Cantón, M.C. Vaquero and I. Marigómez. - 2000. Hediste (Nereis) diversicolor as bioindicator of metal and organic chemical bioavailability: A field study. Ecotox. Environ. Rest., 3(1): 7-15.

Farke, H. and E.M. Berghuis. - 1979. Spawning, larval development and migration of Arenicola marina under field conditions in the Western Wadden Sea. Netherlands J. Sea Res., 13(3/4): 529-535.

Ferreira, J.G., Simas, T., Nobre, A., Silva, M.C., Schifferegger, K., and Lencart-Silva, J., 2003. Identification of Sensitive Areas and Vulnerable Zones In Transitional and Coastal Portuguese Systems. Application of the United States National Estuarine Eutrophication Assessment to the Minho, Lima, Douro, Ria de Aveiro, Mondego, Tagus, Sado, Mira, Ria Formosa and Guadiana systems. INAG/IMAR, Portugal, 2003.

Fidalgo e Costa, P. - 2001. Bio-ecologia e produção do poliqueta Nereis diversicolor O.F. Müller. Recurso zoológico de ambientes costeiros. Ph. D. thesis, Univ. Lisboa.

Howard, L.S. and B.E. Brown. - 1983. Natural variations in tissue concentration of $\mathrm{Cu}$, zinc and iron in the polychaete Nereis diversicolor. Mar. Biol., 78: 87-97.

Langston, W.J., G.R. Burt, and N.D. Pope. - 1999. Bioavailability of metals in sediments of the Dogger Bank (Central North Sea): A mesocosm study. Est. Coast. Shelf Sci., 48: 519-540.

Lee, B.G., J.S. Lee, S.N. Luoma, H.J. Choi, and C.H. Koh. -2000. Influence of acid-volatile sulfide and metal concentrations on metal bioavailability to marine invertebrates in contaminated sediments. Environ. Sci. Tech. 34: 4517-4523.

Lichtenegger, H.C., T. Schöberl, J.T. Ruokolainen, J.O. Cross, S.M. Heald, H. Birkedal, J.H. Waite, and G.D. Stucky. - 2003. Zinc and mechanical prowess in the jaws of Nereis, a marine worm. Biochemistry., 100(16): 9144-6149.

Loring, D.H. - 1991. Normalization of heavy-metal data from estuarine and coastal sediments. J. Mar. Sci, 48: 101-115.

MacDonald, D.D., R.S. Carr, F.D. Calder, E.R. Long and C.G.
Ingersoll. - 1996. Development and evaluation of sediment quality guidelines for Florida coastal waters. Ecotoxicology, 5: 253-278.

Luoma, S.M. and G.W. Bryan. - 1978. Factors controlling the availability of sedimen-bound lead to the estuarine bivalve Scrobicularia plana. J. Mar. Biol. Ass. U.K., 58: 793-802.

Méndez, N. and F. Páez-Osuna. - 1998. Trace metals in two populations of the fireworm Eurythoe complanata from Mazatlán bay: effect of body size on concentrations. Environm. Pollut., 102: 279-285.

Morrisey, D.J., A.J. Underwood and L. Horwitt. - 1996. Effects of copper on the faunas of marine soft-sediments: An experimental field study. Mar. Biol., 125: 199-213.

Nipper, M. and S. Carr. - 2003. Recent advances in the use of meiofaunal polychaetes for ecotoxicological assessments. Hydrobiologia, 496: 347-353.

Olive, P.J.W., N. Bury, P.B.D. Cowin, R.R. Smithard, N. DePauw and J. Joyce. - 1991. Commercial production of polychaetes for angling: Implications for mainstream aquaculture. Aquaculture and the Environment. EAS, Special publication, 14: 241-242.

Paxton, H. - 2006. Replacement of adult maxillary jaws in Eunicidae (Polychaeta). Sci. Mar., 70S3: 331-336.

Rainbow, P., D.J.H. Phillips, and M.H. Depledge. - 1990. The significance of trace metal concentrations in marine invertebrates: a need for laboratory investigation of accumulation strategies. Mar. Pollut. Bull., 21: 321-324.

Rantala, R.T.T. and D.M. Loring. - 1977. A rapid determination of 10 elements in marine suspended particulate matter by atomic absorption spectrophotometry. Atom. Absorp. Newsl., 16: $51-52$.

Vale, C. and C. Cortesão. - 1988. Zinc, cooper and cadmium in the oyster Crassostrea angulata from the Sado estuary (Portugal). In: M. Astruc and J.N. Lester Public. Division (eds.), Heavy metals in the Hydrological cycle, pp. 257-264. Selper Ltd, London.

Villares, R., X. Puente and A. Carballeira. - 2003. Heavy metals in sandy sediments of the rìas baixas (NW Spain). Environ. Monit. Assess., 83: 129-144.

Voss-Foucart, M.F., M.T. Fonze-Vignaux and C. Jeuniaux. - 1973. Systematic characters of some polychaetes (Annelida) at the level of the chemical composition of the jaws. Biochem. Syst., 1: $119-122$.

Wright, P. and C.F. Mason. - 1999. Spatial and seasonal variation in heavy metals in the sediments and biota of two adjacent estuaries, the Orwell and the Stour, in eastern England. Sci. Total Environ., 226: 139-156.

Zauke, G.P, B. Clason, V.M. Savinov and T. Savinova - 2003. Heavy metals of inshore benthic invertebrates from the Barents Sea. Sci. Total Environ., 306(1-3): 99-110.

Zhou, Q., P. Rainbow and B.D. Smith. - 2003. Tolerance and accumulation of the trace metals zinc, copper and cadmium in three populations of the polychaete Nereis diversicolor. J. Mar. Biol. Ass. U.K., 83: 65-72.

Scient. ed.: J. Albaigés.

Received June 18, 2008. Accepted January 22, 2009.

Publlished online May 19, 2009. 